\title{
Application of Newton's law of cooling in production line
}

\section{Aplicación de la ley de enfriamiento de Newton en Línea de producción}

\author{
HERRERA-SÁNCHEZ, Gustavo †*, MORAN-BRAVO, Luz del Carmen, GALLARDO-NAVARRO, \\ José Luis and SILVA-JUÁREZ, Alejandro
}

Universidad Tecnológica de Puebla, División de Mantenimiento Industrial

ID $1^{\text {st }}$ Autor: Gustavo, Herrera-Sánchez / ORC ID: 0000-0001-5276-5062, Researcher ID Thomson: F-6595-2018, arXiv Author ID: herreragh, CVU CONACYT ID: 459805

ID $1^{\text {st }}$ Coautor: Luz del Carmen, Moran-Bravo / ORC ID: 0000-0002-7096-2075, Researcher ID Thomson: G-2686-2018, arXiv Author ID: XVRU3-JP9XUY, CVU CONACYT ID: 75419

ID $2^{\text {nd }}$ Coautor: José Luis, Gallardo-Navarro / ORC ID: 0000-0001-7954-4905, Researcher ID Thomson: F-8798-2018, arXiv Author ID: GALLARDO\#1, CVU CONACYT ID: 629796

ID $3^{\text {rd }}$ Coautor: Alejandro, Silva-Juárez / ORC ID: 0000-001-8473-9803, Researcher ID Thomson: F-6969-2018, arXiv Author ID: alejandrosilva1, CVU CONACYT ID: 637028

DOI: $10.35429 / J I O .2019 .5 .3 .1 .7$

Received July 28, 2019; Accepted December 20, 2019

\section{Abstract}

The objective of this study is to solve the problem of the packaging process when handling canned food. In the thermal process the sterilization of the food product is carried out in addition to the cooking, a thermal shock is created to eliminate $100 \%$ the microorganisms that can damage the product; in addition it must comply with the NOM-130-SSA1-1995, Goods and services. Food packed in hermetically sealed containers and subjected to heat treatment. The temperature of exit is of $75^{\circ} \mathrm{C}$, not being pertinent for the handle of the finished product and in agreement with the internal specification of the company, the temperature for the handle and packaging must be of $40{ }^{\circ} \mathrm{C}$. The methodology used is Newton's Law of Cooling for heat transfer, which states that the rate of heat exchange between an object and its environment is proportional to the temperature difference between the object and the environment. The differential equation is solved and the results obtained are validated with tests in the production line. The main contribution is that science is applied to solve a problem in a production line.

Cooling law, Temperature, Thermal process

\section{Resumen}

El objetivo de este estudio es resolver la problemática que tiene el proceso de empaque al manipular alimentos enlatados. En el proceso térmico se lleva a cabo la esterilización del producto alimenticio además del cocimiento, se crea un choque térmico para lograr eliminar al $100 \%$ los microorganismos que pueden dañar al producto, además se debe cumplir con la NOM-130SSA1-1995, Bienes y Servicios. Alimentos envasados en recipientes de cierre hermético y sometido a tratamiento térmico. La temperatura de salida es de $75^{\circ} \mathrm{C}$, no siendo pertinente para el manejo del producto terminado y de acuerdo con la especificación interna de la empresa, la temperatura para el manejo y embalaje debe ser de $40^{\circ} \mathrm{C}$. La metodología empleada es la Ley de enfriamiento de Newton para la transferencia de calor, la cual establece que la tasa de intercambio de calor entre un objeto y su entorno es proporcional a la diferencia de temperatura entre el objeto y el entorno. Se plantea la ecuación diferencial y los resultados obtenidos se validan con pruebas en la línea de producción. La principal contribución es que se aplica la ciencia para resolver un problema en una línea de producción.

Ley de enfriamiento, Temperatura, Proceso térmico

Citation: HERRERA-SÁNCHEZ, Gustavo, MORAN-BRAVO, Luz del Carmen, GALLARDO-NAVARRO, José Luis and SILVA-JUÁREZ, Alejandro. Application of Newton's law of cooling in production line. Rinoe Journal-Industrial Organization. 2019. 3-5:1-7

*Correspondence to Author (herreragh@yahoo.com..mx)

$\dagger$ Researcher contributing first author. 


\section{Introduction}

Mathematical modeling of industrial processes is an approach that allows us to study reality through algorithms. Its application occurs in different fields of knowledge such as architecture (Zappitelli, 2019), vitamin adsorption (Vélaquez Campoy, 2019), the statistical validation of virtual instruments (Herrera S., Silva J., Salazar P., \& Gallardo N. , 2017), among others.

The modeling for thermodynamic processes has been used as in entropy-time relationship in an isochromic adiabatic system (Ros, 2019) with constant volume, in the transfer of heat in food (Vela P., 2013). In food, heat treatments are applied (Pérez \& Sosa, 2013) with the purpose of increasing stability, cooking or heating them for consumption either for humans or domestic animals.

The heat transfer is carried out by different modes. Conduction occurs when there is a temperature gradient in a solid or fluid stationary medium. Convection is the temperature gradient between a surface and a moving fluid. Thermal radiation occurs between two surfaces in the absence of a medium.

Likewise, mathematical models provide one of the basic tools to describe physical processes and to explain and predict behavior in varied conditions. Computer science has stimulated a greater interest in the development of mathematical models of heat transfer in food processes such as sterilization, scalding, freezing, refrigeration and frying (Alvis, Caicedo, \& Peña, 2010; Califano \& Cálvelo, 1983; Pelegrina, Echarte, \& Sherwood, 2000; Sosa, Orzuna, \& Velez, 2006).

On the other hand, one of the applications of heat transfer is Newton's cooling law, which has been applied since the beginning of the 18th century (Besson, 2010), one of its applications is the simulation of the cooling system and the detection of car failures (Gupta, 2015).

In food processes, heat transfer is a key element in controlling temperature. In this case, the canning process is used for food preservation. Canning is a common technique for food preservation and commercial sterilization, this process destroys microorganisms and enzymes that harm food (Martín G., 2019).
The study was carried out in a food company, located in the State of Puebla, a problem is detected in the thermal process of a BAD production line (see figure 1), when a can of food ends its process in the autoclave immediately goes to the However, when it enters the packing area, it cannot be handled for its packaging because it has an inadequate temperature for handling. Being the problem to solve located in the area of packaging, which is linked to the maintenance area. The importance of finding a numerical value with respect to the time that a can should remain in the cooling tub for subsequent handling for its packaging. This results in delays in shipments of finished product and low productivity in the packaging area resulting in inadequate customer service.

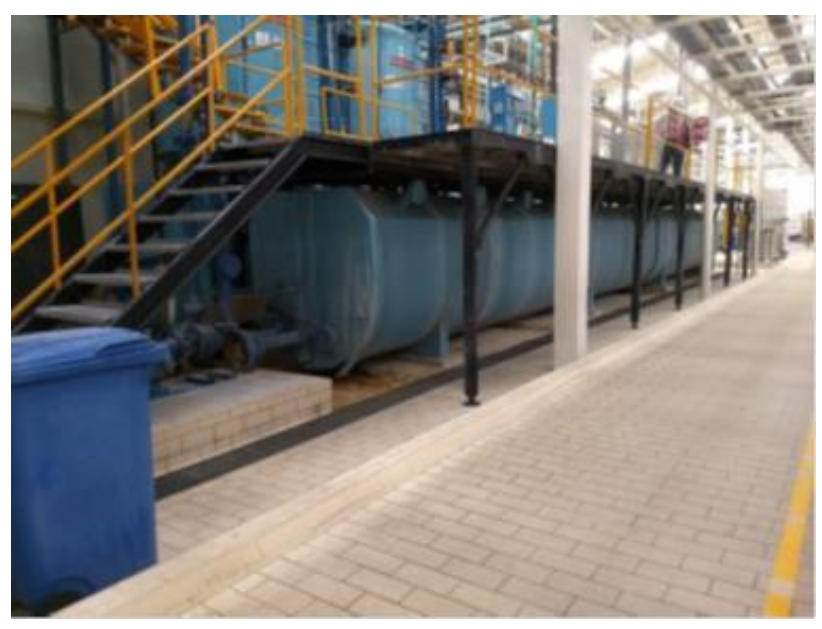

Figure 1 Thermal process BAD line

Source: Productos Alimenticios La Morena S.A.

In general, during a heat treatment of a canned food, the heat transfer mechanisms are conductive for solids (Pérez \& Sosa, 2013), convection for liquid foods, convection and conduction for liquid foods containing particles and convection followed of conduction for liquid foods that contain starch or exhibit high viscosity (Erdogdu, Uyar, \& Koray, 2010).

In the production of peppers, preserves and canned sauces several processes are carried out to reach the final product, the main one is the thermal process, where sterilization of the food product is done in addition to cooking, and an adequate thermal shock is performed to achieve $100 \%$ eliminate microorganisms that can harm the product and mainly the end customer. Table 1 shows production data as operating parameters of the BAD production line. 
At this time, it is not possible to force the cooling of the cans by other techniques, since technical analyzes have to be done in reference to food safety and there are no financial resources available.

\begin{tabular}{|l|r|} 
Dairy produce & 8,975 cans \\
Weekly production & 62,825 cans \\
\hline Ideal operating speed & 200 cans per minute \\
Current operating speed & 180 cans per minute \\
Rejections & 350 cans \\
Reprocessing & 250 cans \\
\hline
\end{tabular}

Table 1 Data from the BAD production line Source: Own elaboration with data of the company Productos Alimenticios La Morena S.A.

Therefore, it is important to find a numerical value for the cooling temperature with respect to the surrounding temperature by Newton's cooling law and thus reduce the temperature in the cans that pass to the packing area, being the purpose of this study. On the other hand, Newton's cooling law governs (Barragán, 2009) the temporal evolution of heat transfer processes. Heat transfer is energy in transit due to a temperature difference (Incropera \& De Witt, 1999).

Currently the thermal process works at an output speed of 4 minutes per can, the main problem is that the can when leaving the cooling tub does not have the proper temperature for its packaging, the temperature according to the process path of The company is $40^{\circ} \mathrm{C}$, so claims are received from the packaging area with the argument that the can is too hot, likewise, you do not have adequate time to reach that temperature, because the temperature of the can at the exit is $75^{\circ} \mathrm{C}$.

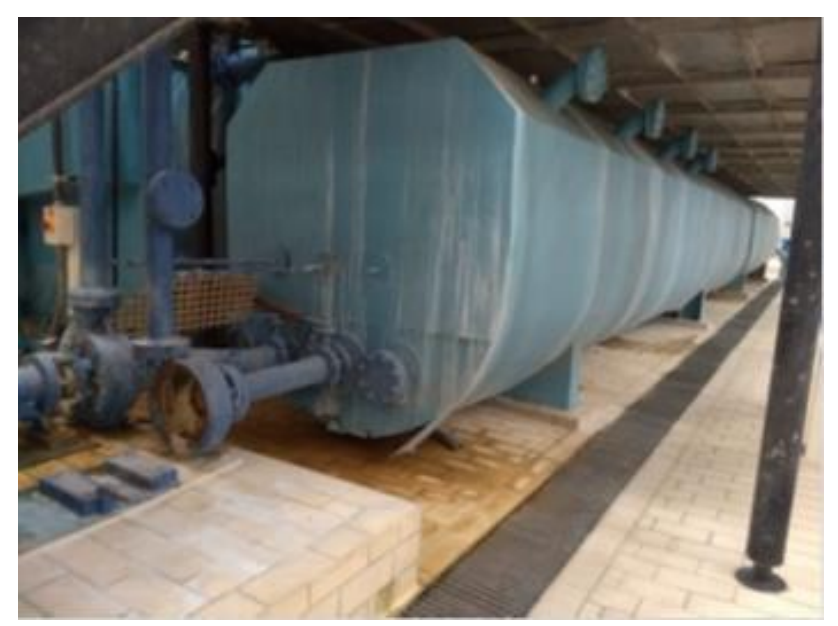

Figure 2 BAD Cooling Tub

Source: Productos Alimenticios La Morena S.A.
The heat convection mode is the one that is developed in the MALO production line, since there is a surface with a temperature gradient in a fluid. If we express the convection effect by Newton's cooling law, the following equation is obtained (Holman, 1999):

$q=h\left(T_{o}-T_{f}\right)$

Where the heat transfer rate is related to the gradient between the temperature of the object and the fluid, which is heat transfer rate, $\mathrm{T}_{\mathrm{o}}$ object temperature, $\mathrm{T}_{\mathrm{f}}$ fluid temperature and $\mathrm{h}$ is the heat transfer coefficient by convection.

This thermodynamic process is represented by a first-order ordinary differential equation.:

$F\left(x, y, y^{\prime}\right)=0$

Thus, Newton's Law of Cooling states that the speed with which an object cools is directly proportional to the difference between its temperature and that of the surrounding environment (Alvarado, 2019). If $\mathrm{T}=\mathrm{T} \backslash \operatorname{left}(\mathrm{t} \backslash$ right) $\backslash$ represents the temperature of an object at time $t$ and T_mes the constant temperature of the medium, the determination of the thermodynamic function for the production line is the mathematical model of an ordinary differential equation (ODE):

$\frac{d T}{d t}=k\left(T(t)-T_{m}\right), k<0$

Then, with the application of Newton's cooling law, a quantitative solution will be found for the BAD production line. With the application of Newton's Law of Cooling, it is expected that the can at the exit of the thermal process has the appropriate temperature for handling in the packing area and, above all, ensure that this temperature meets the appropriate thermal shock to kill microorganisms that damage to the product in accordance with the norm NOM 130-SSA11995, Goods and Services. Food packaged in sealed containers and subjected to heat treatment. Sanitary provisions and specifications. The specific rule that the cooling of the containers after the heat treatment must be carried out with chlorinated water, whose final concentration will be at least $0.5 \mathrm{mg} / \mathrm{kg}$ of residual chlorine, looking for an internal product temperature of approximately $40^{\circ} \mathrm{C}$ being able to effect further treatment with cold air.

HERRERA-SÁNCHEZ, Gustavo, MORAN-BRAVO, Luz del Carmen, GALLARDO-NAVARRO, José Luis and SILVAJUÁREZ, Alejandro. Application of Newton's law of cooling in production line. Rinoe Journal-Industrial Organization. 2019 
On the other hand, for the solution of this problem, another alternative is to apply the statistical method of Design of Experiments $2 \mathrm{k}$ having as a response variable the residence time of the can in the cooling tub and the factors will be the inlet temperature, outlet temperature and speed. The design of experiments can be considered as an evolutionary process (Napolitano, 2006) whose objective is the continuous improvement of the processes, in this case the BAD production line.

One technique that can also be used is mathematical optimization, this is a non-linear case, where decision variables are involved that form an objective function that seeks to maximize or minimize subject to structural constraints, such as the case of mathematical optimization in industrial processes (Fernández Bes, S / f).

\section{Method}

The heat transfer rate is determined by Newton's Cooling Law that represents the overall effect of convection (Pérez \& Sosa, 2013). The variables involved in a thermodynamic process are the pressure, volume, temperature and structure of the food, with temperature being one of the most important variables, maintaining constant pressure and volume (Gómez Daza, 2016).

On the other hand, the purpose of differential equations is to analyze the process of change in reality, for this study in an industrial process. In the analysis of natural phenomena, whether physical or chemical, variables related to exchange rates appear through the general laws of nature that regulate these phenomena (Molero, Salvador, Menarquez, \& Garmendía, 2019).

In our study it is a chemical phenomenon related to thermodynamics and heat transfer and a mathematical analysis is applied. The focus of the study is analytical for Newton's Law of Cooling as a separable first order differential equation. The assumptions of the model are:

It is assumed that the ambient temperature remains constant $\mathrm{T}_{\mathrm{m}}$.

That the temperature of the can is the same as its surface, that is, a constant cooling.
The current conditions are as follows: The 200 gram jalapeno cans leave the thermal process at a temperature of $75 \mathrm{deg}$ and enter a 35 deg water cooling tub when running the tub for 2 minutes, the can has a average temperature of $60^{\circ} \mathrm{C}$, finally obtaining a production rate of 4 cans per minute.

With a temperature of the cooling tub of $\mathrm{T}_{\mathrm{m}}=35 \mathrm{deg}$, ODE remains as:

$\frac{d T}{d t}=k\left(T-35^{\circ} \mathrm{C}\right)$

Solving the separable ODE

$T=c e^{k t}+35$

Finding the value of $\mathrm{C}$ with the initial temperature $\mathrm{T}_{0}=75 \mathrm{deg}$ in the time 0 minutes of band travel in the cooling tub.

$75=c e^{k t}+35$

The ODE is:

$T=40 e^{k t}+35$

Defining the value of the convection heat transfer mode constant with a can temperature of $T=60^{\circ} \mathrm{C}$.

$60=40 e^{2 k}+35$

The final ODE is

$T=40 e^{-0.235 t}+35$

\section{Results}

Currently, the time it takes for a can to pass through the cooling tub is 4 minutes. When we substitute time $\mathrm{t}=4$ minutes in equation 9 , the following temperature is obtained.

$T(4)=40 e^{-0.235(4)}+35=50.63^{\circ} \mathrm{C}$

If the desired final temperature is $\mathrm{T}=40$ $\backslash$ degc, we substitute in equation 9 and obtain the time value:

$40=40 e^{-0.235 t}+35$

The time required to obtain a temperature of $40 \mathrm{deg}$ for handling the can in the packing area is about 8.85 minutes. 
Comparing the current conditions with those proposed by means of the cooling law: an output temperature of $50.63 \mathrm{deg}$ is obtained on the BAD line with a time of 4 minutes, which does not comply with the requirements of NOM 130-SSA1-1995 . On the other hand, applying the Newton cooling equation with a time of 8.85 minutes will obtain an outlet temperature $40 \mathrm{deg}$ for the jalapeno can of 200 grams complying with the provisions of NOM 130-SSA1-1995.

In graph 1, it is observed how the temperature is inversely proportional to the cooling time, that is, if the time increases, the temperature decreases. When the can is submerged in the cooling tub of the production line, reaching the temperature of $40 \mathrm{deg}$ approximately 8.85 minutes.

With the application of the results with Newton's law of cooling, tests are performed to reduce the speed of the band in the cooling tub (20 speed reductions), each speed is changed per minute.

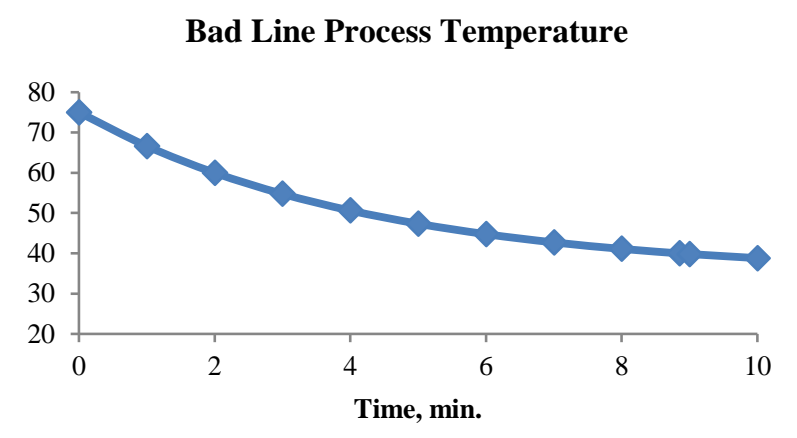

Graphic 1 Equation $\mathrm{T}=40 \mathrm{e}^{-0.235 \mathrm{t}}+35$. Source: Own Elaboration

In table 2, the different values for temperature with respect to time are observed by equation 9.

\begin{tabular}{|l|r|}
\hline Time, minutes & Temperature, $^{\circ}$ \\
\hline 0 & 75.00 \\
\hline 1 & 66.62 \\
\hline 2 & 60.00 \\
\hline 3 & 54.76 \\
\hline 4 & 50.62 \\
\hline 5 & 47.35 \\
\hline 6 & 44.76 \\
\hline 7 & 42.72 \\
\hline 8 & 41.10 \\
\hline 8.85 & 39.99 \\
\hline 9 & 39.82 \\
\hline
\end{tabular}

Table 2 Temperature behavior in the production line with the cooling law

Source: Own Elaboration
With these results, the estimated time of the cans in the cooling tub is 8 minutes to achieve a temperature of $41,103^{\circ} \mathrm{C}$, see table 3 . Consequently, decisions have to be made regarding this since the daily and weekly production will be affected in a matter of its quantity.

\begin{tabular}{|l|l|l|}
\hline \multicolumn{1}{|c|}{ Values } & Time & Temperature \\
\hline Initials & 0 & 75 \\
\hline Current & 4 & 50.625 \\
\hline Ideal & 8 & 41.103 \\
\hline
\end{tabular}

Table 3 Temperature behavior in the production line with the modifications according to the conditions of the BAD production line

Source: Own elaboration with company data Productos Alimenticios La Morena S.A.

\section{Acknowledgement}

We thank the company Productos Alimenticios La Morena for the development of this study in its MALO production line allowing the TSU in Industrial Area Maintenance of the Technological University of Puebla, Jaramillo Guevara Naim Abdalid, López Peralta Mariela and Rosas Javier Ana Karen that will develop and implement this project.

\section{Conclusions}

The time required to comply with the pasteurization process and the operating temperature required by NOM 130-SSA1-1995 has been determined by studying heat transfer and Newton's cooling law. Consequently, an improvement in the handling of cans in the packed process has been achieved.

The production line currently has a production rate of 180 cans per minute and its standard is 200 cans per minute. Then, other variables such as the temperature of the tub water at $35 \mathrm{deg}$ have to be analyzed if it can be increased without affecting the specifications of the thermal process, as well as the capacity of the cooling tub.

It is important to consider Newton's cooling law with a fractional derivative approach (Gómez Aguilar \& Razo Hernández, No. 61 January - April 2014) to have a greater precision of the thermal shock process and compare the results obtained. 
In terms of food there are also studies of the application of fractional derivatives (Mondol, Gupta, Das, \& Dutta, 2018), so for the future it is convenient to apply this technique to compare its results. On the other hand, there are also other forms of pasteurization of thermal processes such as the electric field technique (Pulsed Electric Field, PEF processing) as an alternative to change the pasteurization process with temperature as the main factor (Fernández Bes, S / f ). PEF technology involves the application of electrical impulses to liquid or semi-liquid foods located between two electrodes. This technique can be used for nonthermal pasteurization of food at low or moderate temperatures.

Also, High Intensity Electric Pulses is a non-thermal food preservation technology is another alternative to conventional heat-based conservation technologies (Rivas Soler, 2012). This technology is characterized by allowing a microbiologically safe product to be obtained, with greater respect for nutritional components than conventional heat treatment. These alternatives will have to comply with NOM 130SSA1-1995, as well as other international standards such as ISO 22000: 2005 and the Hazard Analysis and Critical Control Points system; (Hazard Analysis and Critical Control Points; for its acronym in English).

However, with the current conditions of the company's BAD production line, the best option is the application of Newton's Cooling Law. The cost - benefit will have to be studied so that in the future, changing the current thermal technique to a non-thermal technique such as those mentioned above.

\section{References}

Alvarado, A. (2019). Introducción a las ecuaciones diferenciales ordinarias de primer orden. Curso Ed EX. Guatemala, Guatemala.

Alvis, A., Caicedo, I., \& Peña, P. (2010). Determinación del Coeficiente de Transferencia de Calor a Través de una Aplicación de Computadoras. Información Tecnológica Vol. 21(5), 13-20.

Barragán, D. (2009). Producción de entropía y ley de enfriamiento de Newton . REVISTA INGENIERÍA E INVESTIGACIÓN VOL. 29 No. 2, 88-93.
Besson, U. (2010). The History of the Cooling Law: When the Search for Simplicity can be an Obstacle. Science \& Education. 21, 1-26.

Califano, A., \& Cálvelo, A. (1983). and mass transfer during the warn water blanching of potatoes. Journal of food Science. 48(3), 220225.

Erdogdu, F., Uyar, R., \& Koray, T. (2010). Experimental comparison of natural convection and conduction haet transfer. Journal of food process engineering 33, 85-100.

Fernández Bes, A. (S/f). Tesis: Optimización matemática en procesos industriales. Aplicación al estudio de aparatos de tratamiento de alimentos por campos eléctricos. Madrid: Universidad Complutense Madrid.

Gómez Aguilar, J., \& Razo Hernández, J. (No. 61 Enero - Abril 2014). Ley de enfriamiento de Newton de orden fraccionario. Investigación y Ciencia de la Universidad Autónoma de Aguascalientes , 12-18.

Gómez Daza, J. (2016). La termodinámica: una herramienta para el análisis en química de alimentos. UGCiencia 22, 173-192.

Gupta, R. (2015). A Simulink Model for an Engine Cooling System and its Application for Fault Detection in Vehicles. New Delhi, India.

Herrera S., G., Silva J., A., Salazar P., M., \& Gallardo N., J. (2017). Validación estadística del instrumento virtual para desbalanceo dinámico en dos planos mediante un diseño de experimentos 22. Revista de Innovación Sistemática Vol 1 No 3 , 1-9.

Holman, J. P. (1999). Transferencia de Calor. México: CECSA.

Incropera, ,. F., \& De Witt, D. P. (1999). Fundamentos de transferencia de calor. México: Prentice Hall.

Martín G., P. (5 de septiembre de 2019). Hostelería Samanca.es. Obtenido de https://www.hosteleriasalamanca.es/opinion/ma ria-pilar-martin/conservacion-alimentosenlatado-embotellado-vacio.php 
Molero, M., Salvador, A., Menarquez, T., \& Garmendía, L. (6 de septiembre de 2019). Ecuaciones diferenciales en el mundo físico. Integración elemental. Obtenido de http://www2.caminos.upm.es/Departamentos/m atematicas/Fdistancia/PIE/Analisis\%20matemat ico/Temas/C07_Ecuaciones_diferenciales.pdf

Mondol, A., Gupta, R., Das, S., \& Dutta, T. (2018). An insight into Newton's cooling law using fractional calculus. Journal of Applied Physics 123, 1-9.

Napolitano, H. (2006). Diseño de experimentos. Industria\&Química. Educación en Ciencias Químicas No. 354, 62-69.

Pelegrina, A., Echarte, R., \& Sherwood, G. (2000). Cálculo de las propiedades de aire húmedo y su aplicación en la simulación de procesos. Universidad Politécnica de Valencia. Valencia., 7-23.

Pérez, \& Sosa. (2013). Mecanismos de transferencia de calor que ocurren en tratamientos térmicos de alimentos. Temas selectos de Ingeniería de Alimentos 7 -1, 37-47.

Rivas Soler, A. (2012). Tesis: Aplicación de Pulsos Eléctricos de Alta Densidad en una bebida mezcla de zumo de naranja y leche: Efectos sobre Escherichia coli, Saccharomyces. Valencia: Universidad Poltécnica de Valencia.

Ros, F. (5 de Septiembre de 2019). EntropyTime Relationship in an Isochoric Adiabatic System. Obtenido de Instituto de Química Médica (IQM): http://hdl.handle.net/10261/184108

Rosas, A. K., López, M., \& Jaramillo, N. (2018). Reducción de temperatura de latas elaboradas en Productos Alimenticios La Morena S.A. Puebla: División de Mantenimiento Industrial, UTP.

Schwartzberg, H. G., \& Chao, R. (1982). Solute diffusivities in leaching process. Food Technology 3(2), 73-82.

Sosa, M., Orzuna, R., \& Velez, J. F. (2006). Mass, Thermal and quality aspects of deep-fat frying of pork meat. Journal of Food Engineering 77(3), 731-738.
Vela P., F. G. (2013). Tesis: Aplicación de transferencia de calor en el procesamiento de alimentos. Perú: Universidad Nacional de la Amazonia Peruana.

Vélaquez Campoy, A. (2019). Microcalorímetro isotérmico de valoración de alta sensibilidad. Aplicación al estudio de la adsorción de proteinas sobre coloides poliméricos. Granada: Universidad de Granada, .

Zappitelli, M. P. (4 de Septiembre de 2019). Investigación Joven, 6 (Especial), 188. Obtenido de MODELACIÓN DE PROCESOS DE PROPAGACIÓN DE FISURAS EN ESTRUCTURAS DE HORMIGÓN: https://revistas.unlp.edu.ar/InvJov/article/view/ 7119 